\title{
Portuguese farming firms' growth: do human capital and managerial capabilities matter?
}

\author{
NATÁLIA BARBOSA*
}

DOI: $10.30682 / \mathrm{nm} 2001 \mathrm{~g}$

JEL codes: L11, Q12, J24

\begin{abstract}
This paper examines the underlying factors that might shape firm's growth in the farming sector. In particular, we investigate the effects of human capital and managerial capabilities on growth of Portuguese farming firms during 2003-2007. Relying on econometric models that control for survivorship bias, the results indicate that younger and top-educated employees are likely to foster farming firm's growth. On the other hand, the effect of managerial capabilities appears to be somewhat weak on firms without separation between ownership and management. The flexibility to hire specialised and multidisciplinary management teams with managerial capabilities appears to yield economic payoffs on the farming sector.
\end{abstract}

Keywords: Growth, farming firms, managerial capabilities, human capital, firm-level data

\section{Introduction}

In Portugal, as well as in other developed countries such as the members of European Union (EU), the importance of agriculture in the economy has substantially decreased over time. The share of employment in agriculture tend to be higher than the share of value added coming from agriculture, suggesting that there are strong incentives for employees moving out of agriculture and into other economic activities (Gollin et al., 2014a). The persistence and magnitude of those incentives stimulate a recent debate around the correct assessment of the agricultural productivity gap and the agricultural productivity differences across countries (see, for instance, Adamopoulos and Restucia, 2014; Gollin et al., 2014a; Gollin et al., 2014b).

In recent years, restoring and expanding agricultural production and productivity has become a goal elected by Portuguese policy makers.
Fostering the agricultural sector was perceived as a way of helping employees to find new job opportunities and assisting economic recovery, in particular by providing a market for non-agricultural goods and services. Accordingly, some policy measures were designed to attract new farmers and the creation of new farming firms, and, hence, to promote the development and growth of the agricultural sector. As a result, there are some measurable effects on farming firms' dynamics. The relative weight of farming firms in the total of Portuguese non-financial firms has increased over the last years and, on average, farming firms report positive growth even though at slow pace. The high dispersion on farming firms' growth is another important feature of the Portuguese agricultural sector. Therefore, understanding the growth of farming firms is a topical issue when it comes to defining policy measures and assessing them.

\footnotetext{
* University of Minho, School of Economics and Management, Braga, Portugal.

Corresponding author: natbar@eeg.uminho.pt
} 
In the EU, differences in farm size and growth are mainly explained by market conditions and policy support, in particular the Common Agricultural Policies (CAP) (Piet et al., 2012). The recent changes on CAP led European farmers to be more connected to market signals, increasing their market orientation by producing products that are demanded by consumers and environmentally sustainable while trying to contribute to the development of rural areas.

Those changes have implied that the drivers of farming firms' growth are now more prone to be routed on market rules, managerial capability, human capital investments, and, to a lesser extent, on technical farming skills. In fact, the intensification of farming firms' market orientation would require an increase in the farming firms' ability to recognise and incorporate new knowledge to agricultural practices, and to adopt cost-reducing/output-increasing technologies, which would contribute to farming firms' growth. The application of scientific research and new knowledge to agricultural and managerial practices can be impacted by farmers' investment in education and human capital in order to increase farming firm's absorptive capacity and ability to recognise and exploit profit opportunities. All those changes create new management issues, but, at the same time, new opportunities for farming firms with adequate and high management capabilities.

Therefore the objective of this paper is twofold. Firstly, the relationship between farming firms' size and growth, employing the Gibrat's (1931) law, is analysed in order to evaluate whether, as occurred in other economic sectors, the rate of growth of a farming firm is independent from its size. Similarly to other economic sectors, several studies test the validity of Gibrat's law applied to firms in the farming sector, but there is no consensus on that, which calls for further studies in different economic contexts as, for example, Portugal. Moreover, from an economic perspective the violation of Gibrat's law means that there are systematic economic driving forces that shape firms' size and growth, opening ground for sectoral or regional policy measures.

Thus, the second objective is to empirically evaluate the role some observable factors can play in shaping the farming firm's growth pattern, in particular factors related to farmer-specific characteristics and decisions. The rationale for the focus on those specific issues as a moderated factor of farming firm's growth is to assess the extent to which different patterns of managerial abilities and different competences to exploit profit opportunities can provide additional insights on the variation in farming firms' growth and size. In fact, as we will discuss in the following section, there are compelling theoretical reasons to expect the relationship between firm size and growth to be driven by owner's specific characteristics and decisions, especially in terms of human resource management and organizational structure. If so, those factors may have the potential to contribute significantly to structural change based on farming firms' growth. In this sense, this study explores the productive and socio-economic specificities of the Portuguese farming sector in order to better understand farming firms' growth and assist policy design.

The remainder of the paper is organized as follow. Section 2 provides a brief review on the farming firms size-growth relationship and discusses the rationale behind the link between managerial capabilities, human capital and farming firms' growth. The data, empirical variables and econometric approach were discussed in section 3. The next section presents and discusses the empirical estimates on the determinants of farming firms' growth in the light of the key contributions, while section 5 provides the main conclusions and some policy implications.

\section{On the determinants of farming firms' size and growth}

During the last decades, farm structure has been changing. There are a lot of factors that contribute to this phenomenon, factors which could be sorted into two categories: external and internal factors (Villatoro and Langemeier, 2006). Within the external factors are the weather, prices, farm policies and national economic growth. By contrast, within the internal factors, farm size, the type of firm and organization, technology and management skills of the operator are frequently identified as important. 


\subsection{The farm size-growth debate}

The change in the number of farms and its growth is a topic that has received special attention of many authors. Indeed, the size and growth of farming firms is an important indicator of structural changes on farming sector. Eastwood et al. (2010) provide empirical evidence about the farm size across countries and time. They found that countries with higher per capita income tend to have larger average farm size than countries with lower per capita income. Moreover, the variation of farm size among countries is related with economic and technological factors, as well as with some external factors (for example, the share of land to pasture). An interesting result suggests that countries with temperate climate have larger farms, something that is related with the quality of land. Among the European Union members, agricultural effects are often addressed by the Common Agricultural Policy (CAP).

The validity of Gibrat's law is often tested on studies in order to determine if there is an independent relationship between the size of a farm and its growth. In a country-study for Canada, Shapiro et al. (1987) reject the law, where the results show a negative correlation between the size and growth of Canadian farms. Upton and Haworth (1987) study the UK farming sector and the results show a positive relation between initial farm size and its growth, thus rejecting Gibrat's law. Weiss (1999) also rejected the law, for Austria, as well as Bremmer et al. (2002), for the Netherlands. Rizov and Mathijs (2003) analysed the case of farms in a transition economy - Hungary and concluded that older and larger farms tend to survive and the farm growth decreases with farm age, which suggest that farm sizes adjust over time. Melhim et al. (2009) analysed growth and diversification of US corn, wheat, apple and beef farms. Their results show that corn and wheat farms grow faster than the other two farms, and that the apple farm is the most specialized. Moreover, scale economies diminish for large farms and the Gibrat's law is rejected.

Additionally, Piet et al. (2012) considered a French case study in order to analyse farm size inequality and show that agricultural policies affect farm size inequality and are important determinants of the size of farms. Bakucs et al. (2013) attempted to analyse the relationship between size and farm growth in France, Hungary and Slovenia to check the validity of Gabrit's law. Gibrat's law can be rejected for Hungary's farms. In Hungary, small farms seem to grow faster than large farms. Conversely, for French farms there are evidence supporting Gibrat's law, while in Slovenia Gibrat's law is rejected. Under that study, the farm-size growth divergence in Slovenia's farms is motived by large farms, which grow faster than smaller farms. Thus, these results suggest that farm structures depend on production specialization (crops and dairy farms).

\subsection{Managerial capabilities and human capital investments}

Managerial capabilities are pointed as an important determinant of farming firms' growth, as management can influence, for instance, unit costs through technological innovation. For Penrose (1959) the growth of firms is determined by "learning-by-doing", where the managers become more productive as they become more accustomed to their tasks (experience). In this line of reasoning, farmers with more experience could have lower average marginal production costs and may choose to operate larger farming firms. However, managers who spend much time focusing on the firm's expansion divert their attention from operating efficiency. At an optimal growth rate, an increase in firm's growth leads to higher operating costs. Above a certain level of growth, additional diversification has a lower than expected profitability because managers have less time and attention to devote to the operating efficiency of existing activities and the development of new activities (Marris, 1963, 1964). In order to guarantee business survival, farmers need to use efficient commercial strategies, as product diversification given what markets want. This farmer's aim is consistent to the innovation dimension under the entrepreneurship theory, which establish that an entrepreneur should constantly search for new products, markets and methods. 
Studies from McElwee and Robson (2005) and McElwee (2006) suggest three types of skills that farming firm's owners (or their management teams) should have: (i) technical and professional skills related to farming; (ii) information technologies skills, which includes people management, accountancy and finance; and, (iii) networking and entrepreneurial skills for a strategic awareness of the business. In small farming firms management tends to be a personalised process in which the specific characteristics of the owner-manager determine firm's performance. Personal aspects of the owner-farmer determine the quality of the decision-process, upon which depends farming firm's performance and growth. For instance, Bartolini and Viaggi (2013), who intended to identify the determinants of future changes on farming firms, found a positive relation between farm size and age and skills of farmers and geographical location.

However, as a firm grows and the complexity of modern farming operations increases, it may become difficult for the owner-manager-farmer to excel at all management areas (Ford and Shonkwiler, 1994). This calls for some separation between owner-farmer and management team, which bring to the firm heterogeneous managerial capabilities.

Monetary incentives offered to managers, such as bonuses, are often related with firm size, in particular when there is a separation between farmer/owner and managers. In such cases, managers have an incentive to pursue a great growth rate for firms and firm size is an important factor in the "managerial utility function". According to Mueller (1969), for small (young) firms the pursuit of profit maximization is in line with the goals of growth maximization. Firms that are more profitable are expected to grow. These incentives are in accordance with entrepreneur dimensions considered as risk-taking and growth orientated. Under the dimension of risk taking, the entrepreneur should maximize profit in order to avoid the possibility of failure. Indeed, the profit maximization aim is in line with the goal of business growth and activity expansion - growth orientation dimension.

Farming business used to be a traditional activity, a household activity. However, in the EU context, the Common Agricultural Policy (CAP) seems to benefit farmers by giving them the possibility to develop entrepreneur skills by taking responsibility for their business, especially when it comes to small farmers. Moreover, CAP also moves the farmers activity to a market oriented framework, leading to changes in the required skills of farmers (Atterton and Ward, 2007). McElwee (2006) suggest that business-owners have to be strategic facilities in order to create value, such as the expansion of land area, the increase of animal and crop production, or to move into external business. Improving education levels is a great contribution to develop entrepreneurial capabilities in farmers with positive effects on growth and farm business (Pyysiäinen et al., 2006). Moreover, Marsden and Smith (2005) argue that managerial capabilities increase productivity and ensure a great survival rate for European farmers.

However, the farming sector is not a homogeneous one. Farming firms differ in production, competitive environment, or even in their regulatory system. In this way, education and training of farmers is crucial to the development of managerial capabilities required on the agricultural sector (McElwee, 2006). Such managerial capabilities could allow for a more efficient management of human resources, which, in turn, could increase technology adoption and effectiveness in the allocation of scarce resources, as suggested by Zepeda (1990).

Several empirical studies have assessed whether differences in farmer's managerial ability relates to differences in farming firms' performance. Measures of farmer's managerial ability is traditionally based on the farmer's demographic information, even though there is no consensus on what variables measure managerial ability. For instance, Sumner and Leiby (1987) analyse size-growth of farms and its relationship with observed human capital features of the operator based on age, experience and schooling. They found empirical evidence that experience of operator reduces the growth rate of farms, while schooling seems to affect positively farm' size and growth. Kimhi and Bollman (1999) conclude that farmers' age has a positive impact on the size and growth of farms. Rizov and 
Mathijs (2003) found that an increase in human capital improves the effectiveness of farm operators in adopting new technologies, which can explain higher growth and survival rates. More recently, D'Amico et al. (2013) argue that farming firms performance is related to the quality of human capital, while Akimowicz et al. (2013) concluded that farmer-specific characteristics as a measure for human capital do not play a role on farm's size and growth.

Villatoro and Langemeier (2006) also examined the factors that have impact on farm growth. They found that farms with a younger operator grew at a relatively faster rate. Moreover, the growth rate of farms is higher when the managerial ability is also higher. Higher managerial ability seems to allow higher conditions to invest in farm's operations, which, in turn, lead to higher growth rates. Defining human capital as the combination of various factors, such as age, experience and management capabilities of the principal operator, Hadrich (2011) tries to measure the impact of human capital on farm size and growth. In a sample of 15 years time period (1994-2009) for 500 North Dakota farms, Hadrich (2011) found that the age of the main operator, financial management and human resources management are the determinants of farm size growth. With the continuous structural changes in the agricultural sector, farm size-growth requires additional capital and labour. In this way, human capital is an important input of the production function that helps to reduce the marginal cost of production. Sumner (2014) concentrates his study on commercial farms in the US to determine its growth and size determinants. The results found a positive relation between the growth of farms and technological innovations as well as with managerial capabilities.

Nonetheless, most of studies concentrate attention on managerial capabilities and human capital attributed specifically to the farmer-owner demographic characteristics. However, in the modern agricultural sector, their managerial capability may also be disclosed on the ability to hire skilled and qualified employees and to choose a suitable organizational structure.

\section{Data, econometric strategy, and empirical variables}

\subsection{The data}

The farming firm level data was extracted from the annual Quadros de Pessoal survey collected by the Portuguese Ministry of Labour and Social Security since the early 1980s. The mandatory nature of this survey ensures that virtually the whole population of firms with wage earners in Portugal is included in the Quadros de Pessoal dataset. It focuses on the formal sector of the Portuguese economy, encompassing firms with at least one paid employee who contribute and benefit from Social Security.

The main advantages of the Quadros de Pessoal dataset is its longitudinal nature and comprehensiveness at a microeconomic level, allowing the matching, throughout time, of firms, employees, and plants, where they are located. Data at firm level includes the level of employment, characteristics of employees in terms of age, experience and academic qualifications, location, year of start up, legal format, and the main economic activity performed by firms and plants. For the cases where the firm's owner is also a paid employee, there is also information on owner-specific characteristics. We use mainly information on employment and employees' characteristics to compute our empirical variables.

The sample comprises active farming firms showing up, at least in two subsequent years, in the Quadros de Pessoal from 2002 until 2007. A firm is identified as a farming firm if it belongs to one of the 5-digit agricultural sectors defined in the Portuguese economic activity classification based on NACE rev.1. The change on the Portuguese economic activity classification after 2008, without a unique linkage between the old and the new classification, and the lack of firm level information after 2009 for several years prevent us from analysing a different time period. Therefore, the final sample comprises 9,316 farming firms observed from 2002 to 2007, but with gaps, corresponding to 23,078 observations. Table 1 provides some descriptive statistics of 
Table 1 - Descriptive statistics of farming firm's size and growth rate.

\begin{tabular}{|l|c|c|c|c|}
\hline & Mean & Std. Dev. & Minimum & Maximum \\
\hline Size & & & & \\
Total number of employees & 3.631 & 8.350 & 1 & 287 \\
Size types & & & & \\
$\quad$ Micro firms (less than 6 employees) & 0.858 & 0.349 & 0 & 1 \\
$\quad$ Small firms (6-20 employees) & 0.120 & 0.325 & 0 & 1 \\
$\quad$ Medium firms (21-50 employees) & 0.017 & 0.131 & 0 & 1 \\
$\quad$ Large firms (more than 50 employees) & 0.004 & 0.067 & 0 & 1 \\
\hline Growth rate & & & & 3.497 \\
Annually & -0.010 & 0.369 & -3.446 & 2.484 \\
2003-2007 & -0.067 & 0.652 & $-3-949$ & 3.583 \\
2005-2007 & 0.001 & 0.431 & -3.734 & \\
\hline
\end{tabular}

the sample in terms of farming firm's size and growth rate.

On average, Portuguese farming firms employ four paid workers. The observed size dispersion is considerable with a huge percentage of micro farming firms and a negligible percentage of large firms. This finding is not specific to the agricultural sector. It is a relevant feature of the Portuguese economy; the great proportion of SME's (small and medium enterprises). The agricultural sector seems to accentuate that feature of the Portuguese economy.

Interestingly, the farming firms growth rates show a slightly positive performance over 2005-2007, the three final years. On average, Portuguese farming firms that survive at least two subsequent years report an annual decrease on employment around $1 \%$. However, the annual growth rate shows a positive evolution over the observed time period, which explains the positive growth at the end of the time period. In 2007, the surviving farming firms report an annual growth rate around $0.3 \%$. Firms that show up in the database in 2003 and 2007, suggesting that they are surviving firms over the entire time period, report, on average, a negative growth rate. This seems to indicate that the slightly positive growth at the end of the time period does compensate the negative growth report during the first years of the observed time period.

\subsection{Econometric strategy}

When assessing the underlying firm growth process, in particular the relationship between firm's size and growth dynamics, the Gibrat's (1931) law provides a sort of "null hypothesis", which posit that firm growth follows a purely stochastic process, with growth rates being independent of firm size. Following Chesher (1979), farming firm growth-size relationship was analysed through the estimation of autoregressive models on the firm size time series augmented by a vector of firm-, employees- and owner-specific characteristics in order to assess the impact of those factors on the farming growth rate.

The augmented Chesher-type growth-size relationship was specified as

$$
\begin{aligned}
G R_{i j(t)}= & \Delta s_{i j(t)}=s_{i j(t)}-s_{i j(t-1)}=\left(\eta_{1}-1\right) s_{i j(t-1)}+ \\
& +\left(\eta_{2}\right) s_{i j(t-2)}+\beta \mathbf{z}_{i(t-1)}+\xi_{i j(t)}
\end{aligned}
$$

where $\mathrm{GR}_{\mathrm{ij}}$ is the farming firm's growth rate based on firms differences of the normalized ( $\log$ ) firm size of firm $i$ sector $j, \mathrm{~s}_{\mathrm{ij}}$ is the normalized (log) farming firm size of firm $i$ in sector $j$, $\mathbf{z}_{\mathrm{i}(\mathrm{t}-1)}$ is a vector of measures of firm-, employees- and owner-specific characteristics at the beginning of the growth period (that is, the period $t-1$ to $t$ ) and $\zeta_{\mathrm{ij}}$ is an error term. We use the normalised (log) size, computed by subtracting from the (log) size of each firm in sector $j$ the 
average (log) size of all firms in that sector, in order to eliminate possible trends in the average firm size and to account for agricultural farm diversity due to heterogeneous farm structures and technologies across the agricultural sector. The normalised $(\log )$ size is proportional to the firm's market share (measured by total employment) and, hence, it depends on the distribution of farm types in each agricultural sector.

In order to obtain reliable estimates we have to deal with several econometric problems. The potential serial correlation of the error terms $\zeta_{\mathrm{ij}(t)}$ is solved by the Chesher's (1979) method by assuming that the error term in the primary equation is characterized by an $\mathrm{AR}(1)$ structure, which is already taken into account in equation (1). Correcting the standard errors using a robust estimator of covariance matrix solves the heteroskedasticity of $\zeta_{\mathrm{ij}(t)}$. The other econometric problem is the possibility of survivor bias due to sample selection. Observed data on firm size in two subsequent periods $(t-1, t)$ is only available if firm $i$ is still alive at time $t$. Thus, the conditional expectation of $\mathrm{s}_{i j(t)}$ for surviving firms, given $\mathrm{s}_{i j(t-1)}$ and $s_{i j(t-2)}$, may not be equal to $\eta_{1} s_{i j(t-1)}+\eta_{2} s_{i j(t-2)}$. If this is the case, the growth equation should account for the survivor bias. Otherwise, estimates could omit the impact on growth-size relationship of firms with survival difficulties, which is very likely to be different from that of firms with high probability of survival.

A two-step estimation procedure is applied. In the first step, we estimate a probit selection model from the whole sample (including the survivor firms plus firms that closed or went bankrupt before the end of the time $t$ )

$$
\operatorname{Pr}\left(\psi_{i j(t)}=1\right)=\Phi\left(\alpha \mathbf{z}_{i j(t)}\right)+\xi_{i j(t)}
$$

where $\psi_{i j(t)}$ is an indicator function which takes value 1 if firm $i$ in sector $j$ at time $t$ is still alive and 0 otherwise. The vector $\mathbf{z}_{i j(t)}$ comprises the explanatory variables of the survival function and $\xi_{i j(t)}$ are the error terms that are assumed to be normal. As it occurred with most previous studies (e.g., Lotti et al. (2009), covariates of the survival function are firm size, augmented by its squared terms.
After estimating equation (2) - the survival equation - the inverse of Mills' ratio for each firm is computed. This ratio gives the probability that a firm is still alive at time $t$ over the cumulative probability of a firm's decision on survival. In the second step, the inverse of Mills' ratio is included as an additional covariate in the growth equation - equation (1) -, which is estimated using the selected sample of survivor firms (see Wooldridge, 2002: 564 for details). The additional parameter estimate $-\lambda-$ is the proportion of the covariance between the decision to survive and grow relative to the variation in the decision to survive. A test of survivor bias is therefore a t-test on $\lambda$.

\subsection{Empirical explanatory variables}

Several firm-, employees-, and owner-specific characteristics have been identified as capable of shaping farming firms' dynamics. Aside from firm's size, and based on data availability and theoretical arguments, we consider the following additional specific determinants of farming firm growth: (i) firm's legal format, (ii) employees' age, experience, and academic qualifications, and (iii) owners' age, experience, and academic qualifications.

The legal format of farming firms could be an important indicator of the required managerial capabilities. The majority of farming operations were organized as sole proprietorships, in which there is no separation between ownership, management team and agricultural workers. In these cases, the required managerial capabilities tend to be low as the administrative and legal burden is simplified and most of the market decisions are ruled by associations of farmers in specific sectors, which behave more like plain commercial societies. Furthermore, managerial capabilities are mainly applied by the farm owner, which has to excel at all management areas. However, farm structure has changed in the past years. Many farming firms use now alternative organizational structures, such as limited liability companies (LLC), and operate independently from associations of farmers, which imply higher managerial capabilities. The possible separation between ownership and management allows 
for broad and specialised management expertise and for a multidisciplinary management team. Therefore, a dummy variable, limited liability companies ( $L L C$ ), was defined and it took the value 1 when the organizational structure of the farming firm is LLC, and 0 otherwise.

One way to measure human capital at a firm level is by looking at a workforce's main features. Regarding firm growth, a young, skilled and academically qualified workforce would boost growth as it was discussed in Section 2. Therefore, for each observed farming firm we compute the average of employees' age and the average of employees' years in the firm as a measure for experience and agricultural skills. Additionally, we computed the ratio of top-educated employees (that is, with a college degree) to total number of employees as a measure for intensity of educational attainment at firm level. For the farming firms where the owner is also a paid employee, similar measures of age, experience and academic qualification were computed to measure owner-specific characteristics as proxies for managerial capabilities. Table 2 presents some descriptive statistics of empirical explanatory variables of farming firm's growth, while Table 3 shows correlation coefficients among selected variables.

Looking at human capital features, two remarkable findings seem to emerge. On average, employees and farmer-owners have similar age and experience in farming in the firm. This suggests that there is some sort of replication of human capital investments, judging by employees'

Table 2 - Descriptive statistics of empirical explanatory variables.

\begin{tabular}{|l|r|r|r|r|}
\hline & Mean & Std. Dev. & Minimum & Maximum \\
\hline Legal business format & & & & \\
Limited liability company (LLC) & 0.226 & 0.418 & 0 & 1 \\
\hline Employees-specific characteristics & & & & \\
Age (log) & 3.753 & 0.238 & 2.639 & 4.317 \\
Experience (log) & 1.378 & 0.965 & -3.829 & 4.094 \\
Top-education & 0.009 & 0.066 & 0 & 1 \\
\hline Owner-specific characteristics & & & & \\
Age (log) & 3.784 & 0.253 & 2.890 & 4.317 \\
Top-educated owner & 0.095 & 0.285 & 0 & 1 \\
Experience (log) & 1.691 & 0.920 & -0.693 & 3.951 \\
\hline
\end{tabular}

Table 3 - Correlation coefficients among selected variables.

\begin{tabular}{|l|c|c|c|c|c|c|}
\hline & (1) & (2) & (3) & (4) & (5) & (6) \\
\hline $\begin{array}{l}\text { Legal business format } \\
\text { (1) Limited liability company (LLC) }\end{array}$ & 1 & & & & & \\
\hline $\begin{array}{l}\text { Employees-specific characteristics } \\
\text { (2) Age (log) }\end{array}$ & $-0.046^{* * *}$ & 1 & & & & \\
(3) Experience (log) & $-0.094^{* * *}$ & $0.274^{* * *}$ & 1 & & & \\
(4) Top-education & $0.100^{* * *}$ & $-0.062^{* * *}$ & $-0.037^{* * *}$ & 1 & & \\
\hline Owner-specific characteristics & & & & & & \\
(5) Age (log) & $-0.090^{* * *}$ & $0.154 * * *$ & $0.154^{* * *}$ & 0.021 & 1 & \\
(6) Top-educated owner & $0.098^{* * *}$ & 0.009 & -0.003 & $0.153^{* * *}$ & -0.005 & 1 \\
(7) Experience (log) & $-0.245^{* * *}$ & $0.081^{* * *}$ & $0.081^{* * *}$ & $-0.028^{*}$ & $0.331^{* * *}$ & $-0.038^{* * * *}$ \\
\hline
\end{tabular}

Legend: *, **, and $* * *$ mean that coefficients are statistically significant at $10 \%, 5 \%$, and $1 \%$ level. 
and farmer-owner's demographic characteristics. In addition, if age and experience can be seen as indicators of technical skill and update training, on average, there is a lack of renewal between employees and farmer-owner. On the other hand, if higher age and more experience would lead to better off-farm alternatives of employment, we would observe older and more experienced employees in farming only if they had particularly good technical skills and farm aptitude. The other noteworthy finding is related to top-education among employees and farmer-owners. The percentage of farmer-owners with high education is higher than employees, as it was expected. However, there is a positive and statistically significant correlation between them, suggesting that top-educated owners tend to attain more economic value to high education, by employing more top-educated employees.

Another interesting finding is related to the association between owner-specific characteristics and legal format of farming firms. About a quarter of farming firms are LLC. Younger, less experienced in the firm and top-educated owners seem to prefer that legal format, which usually may allow for a multidisciplinary management team and specialised management expertise.

\section{Empirical results}

The estimation results of alternative growth equations are reported in Table 4. The growth rate is measured on an annual basis. Overall, the results show that farming firm growth dynamics depend on firm size. The hypothesis that farming firm growth follows a purely stochastic process is rejected, implying that farming firms with different sizes attain dissimilar proportionate growth. Moreover, the negative first order autocorrelation coefficient in two subsequent periods indicates that high-growth farming firms tend to grow slower in the subsequent periods, suggesting a reversion to the mean process (i.e. small farming firms having higher average growth rates than larger counterparts). These findings hold for all alternative farming firms' growth models, reinforcing the evidence that there seems to be a reversion to the mean process and a rejection of the Gibrat's law in the
Portuguese agricultural sector. The evidence on a farm size-farm growth convergence, disclosed by a reversion to the mean process, suggests that the maturity and steadiness of farm size-growth equilibrium could be attained in long run.

Further, the estimates associated with the inverse Mills' ratio term $(\lambda)$ indicate that differences between a growth conditional on survival analysis and a growth analysis after controlling for sample selection are significant. In particular, the correlation between error terms (in the growth equation and in the selection equation) suggests that there is a positive selection bias that should be taken into account and provides support to the applied econometric strategy.

\subsection{The role of managerial capabilities and human capital on farming firm's growth}

Looking at other factors beside size, the results suggest that managerial capabilities and human capital have power to shape farming firms' growth. Holding everything else constant, farming firms, organized under a limited liability legal structure, seem to exhibit higher growth rates. Those farming firms usually behave similarly to manufacturing firms in terms of market orientation, access to credit, risk management, competition in labour market and adoption of technological innovations, which require greater managerial capabilities. Furthermore, those capabilities are not restrained to farmer's specific capabilities, as there is room for disconnecting ownership and management and, hence, making it easier for the formation of specialised and multidisciplinary management teams. This finding suggests that managerial capabilities allowed by a specific legal business format have a positive payoff, reckoned by higher growth.

The demand for farming firms to improve their managerial capabilities is further reinforced when we look at models (4) and (5). In these models, the sample only comprises farming firms in which the farmer-owners are employees with management liabilities. This implies that managerial capabilities are mainly concentrated in the farmer-owner and deduced by his/her specific characteristics. Using that sub-sample of farming firms, the legal busi- 
Table 4 - Heckman two-step estimates of farming growth determinants based on annually growth rate.

\begin{tabular}{|c|c|c|c|c|c|}
\hline & & & Model & & \\
\hline & (1) & (2) & (3) & (4) & (5) \\
\hline $\operatorname{Size}_{t-1}\left(\eta_{1}-1\right)$ & $\begin{array}{l}-0.228 * * * \\
(0.016)\end{array}$ & $\begin{array}{c}-0.223 * * * \\
(0.015)\end{array}$ & $\begin{array}{c}-0.216^{* * *} \\
(0.016)\end{array}$ & $\begin{array}{c}-0.120 * * * \\
(0.032)\end{array}$ & $\begin{array}{c}-0.119 * * * \\
(0.032)\end{array}$ \\
\hline $\operatorname{Size}_{\mathrm{t}-2}\left(\eta_{2}\right)$ & $\begin{array}{c}0.198^{* * * *} \\
(0.011)\end{array}$ & $\begin{array}{c}0.196 * * * \\
(0.011)\end{array}$ & $\begin{array}{c}0.192 * * * \\
(0.012)\end{array}$ & $\begin{array}{c}0.115 * * * \\
(0.029)\end{array}$ & $\begin{array}{c}0.114 * * * \\
(0.029)\end{array}$ \\
\hline $\begin{array}{l}\text { Legal business format } \\
\text { Limited liability company (LLC) }\end{array}$ & - & $\begin{array}{c}0.036^{* * *} \\
(0.011)\end{array}$ & $\begin{array}{c}0.033 * * * \\
(0.011)\end{array}$ & $\begin{array}{l}-0.016 \\
(0.024)\end{array}$ & - \\
\hline Employees-specific characteristics & & & & & \\
\hline Age $_{t-1}$ & - & - & $\begin{array}{c}-0.057 * * \\
(0.024)\end{array}$ & $\begin{array}{c}-0.134^{* *} \\
(0.053)\end{array}$ & $\begin{array}{c}-0.133 * * \\
(0.053)\end{array}$ \\
\hline Experience $_{\mathrm{t}-1}$ & - & - & $\begin{array}{c}0.004 \\
(0.006)\end{array}$ & $\begin{array}{l}0.020 \\
(0.016)\end{array}$ & $\begin{array}{c}0.020 \\
(0.016)\end{array}$ \\
\hline Top-education $_{\mathrm{t}-1}$ & - & - & $\begin{array}{c}0.194 * * * \\
(0.073)\end{array}$ & $\begin{array}{l}0.260^{*} \\
(0.149)\end{array}$ & $\begin{array}{l}0.259^{*} \\
(0.149)\end{array}$ \\
\hline Owner-specific characteristics & & - & - & & \\
\hline $\operatorname{Age}_{t-1}$ & - & - & - & $\begin{array}{c}0.009 \\
(0.046)\end{array}$ & $\begin{array}{c}0.008 \\
(0.046)\end{array}$ \\
\hline Top-educated owner $r_{t-1}$ & - & - & - & $\begin{array}{c}0.037 \\
(0.034)\end{array}$ & $\begin{array}{c}0.035 \\
(0.034)\end{array}$ \\
\hline Experience $_{\mathrm{t}-1}$ & - & - & - & $\begin{array}{c}-0.043 * * * \\
(0.016)\end{array}$ & $\begin{array}{c}-0.041 * * * \\
(0.016)\end{array}$ \\
\hline Lambda $(\lambda)$ & $\begin{array}{c}0.139 * * * \\
(0.036)\end{array}$ & $\begin{array}{c}0.159^{* * *} \\
(0.037)\end{array}$ & $\begin{array}{c}0.153^{* * *} \\
(0.036)\end{array}$ & $\begin{array}{c}0.074 * * * \\
(0.045)\end{array}$ & $\begin{array}{l}0.080^{*} \\
(0.045)\end{array}$ \\
\hline Time-specific effects & Yes & Yes & Yes & Yes & Yes \\
\hline $\begin{array}{l}\text { Wald } \chi^{2} \text { test }\left(H 0: \eta_{1}=0 ; \eta_{2}=0\right) \\
{[p \text {-value] }}\end{array}$ & $\begin{array}{l}321.13 \\
{[0.000]}\end{array}$ & $\begin{array}{l}312.10 \\
{[0.000]}\end{array}$ & $\begin{array}{l}273.87 \\
{[0.000]}\end{array}$ & $\begin{array}{c}16.52 \\
{[0.000]}\end{array}$ & $\begin{array}{c}16.28 \\
{[0.000]}\end{array}$ \\
\hline Censored obs. & 22266 & 22266 & 22266 & 22266 & 22266 \\
\hline Uncensored obs. & 6528 & 6528 & 6176 & 1082 & 1082 \\
\hline
\end{tabular}

Legend: Figures in parentheses are robust standard errors (that is, standard errors corrected for heteroskedastic errors and lambda ( $\lambda$ ) estimated). *, **, and $* * *$ mean that coefficients are statistically significant at $10 \%$, $5 \%$, and $1 \%$ level. The probit estimation of selection equation is $\operatorname{Pr}\left(\psi_{i j(t)}=1\right)=\Phi\left(\alpha_{0}+\alpha_{1} s_{i j(t)}+\alpha_{2} s_{i j(t)}^{2}\right)+\xi_{i j(t)}$, where the covariates are firm size, augmented by its squared terms.

ness format has no power to shape farming firm growth. It seems to suggest that it is not the organizational structure by itself that could boost growth but the flexibility it brings to disentangle ownership from management and to get a multidisciplinary management team. When managerial capabilities are strictly on the farmer-owner, that flexibility is at risk and, hence, firm's growth could not arise.
Among the farmer-owner specific characteristics, experience within the firm, as an indicator of managerial capabilities and average marginal production costs, is the only observable characteristic that seems to drive farming firm's growth. Although more experienced farm-owners could operate at lower marginal production costs and bring to the firm more managerial and agricultural skills and, hence, foster growth, the effect of 
farmer's experience on growth is uncertain, as it is also strongly tied to the farm business life cycle. For instance, Weiss (1999) found that farm growth increases with farmer-owner's age until a certain point and then declines, suggesting the existence of a business life cycle highly correlated with farmer-owner's age and experience in farming. If more experienced farm-owners are also those near retirement, then farm size is likely to decrease or remain stable. Furthermore, farmer-owners with more years in the firm are more likely to be facing a succession process, which might have a negative impact on growth. Therefore, in case of the Portuguese agricultural sector, experience in farming does not seem to foster growth as better skills brought by experience may not compensate the negative effects associated with firm business cycle and succession difficulties.

On the human capital side, the estimates reveal that younger and top educated employees promote farming firm growth. Holding everything else constant, a high proportion of employees with a college degree - top educated employees - seems to be an important production input, leading to high growth rate. Similarly, younger employees appear to be an important factor of farming firm growth. This implies that labour efficiency, as a result of human resource management and based on young and top educated employees, has a positive and significant effect on farming firm's growth, regardless of farming firm types. Farming firms employing that kind of employees tend to be more capable of innovating (either technological or organizational innovation), leading to a positive impact on the farming firm growth rate. From a policy point of view, these results could be interpreted as strong support to promote the attraction of young and top educated employees for farming. On the other hand, these results amplify the need to improve managerial capabilities in farming firms in order to successfully compete for labour from other sectors.

\subsection{Robustness checks}

The time span applied to compute farming firm growth could be an important issue. The empirical results discussed previously were based on annual growth computed over the period 2003-
2007. Here, the models were re-estimated using an alternative time span in order to explore the robustness of the findings and to reveal some more detailed knowledge on the driving factors of farming firms' growth. For each farming firm, the growth rate is computed for the whole period instead of year-by-year. This implies that the sample has now a cross-section nature. In particular, Table 5 presents estimates for firm's growth rate over a 5-years period (2003-2007) and Table 6 shows estimates for firm's growth rate over the most recent 3-years period (2005-2007). The explanatory variables were measured at the beginning of the period used to compute growth rate.

Overall, the results reveal that there is a significant turbulence in the Portuguese farming sector with respect to the number of firms. Looking at the entire sample period (2003-2007), only $41.6 \%$ of farming firms survive, while the most recent period (2005-2007) reveal that the Portuguese farming sector has been attracting a significant number of new firms but a small percentage of them (less than 25\%) survive and grow. Most interestingly, the rejection of the Gibrat's law and the existence of a farm size-farm growth convergence process are findings that hold valid, regardless of model or time span.

Furthermore, the estimates disclose some hints on what seem to be the changes over time on the driving factors of farming firms' growth. At the beginning of the sample period, and holding everything else constant, the age of farmer-owner seems to be an important factor, with older farmer-owners having higher growth rate over a 5 -year period. On the other hand, the experience within the firm seems to maintain the negative impact on the farming firm's growth. This seems to have contradictory effects.

However, experience within the firm implies an approach to the end of business life cycle that, by shortening the time span within which the gains from growth can be achieved, explain the negative effect on farming firm's growth. Instead, holding farmer's experience within the firm constant, older farmers could bring skills and knowledge to the firm that foster growth in farming firms that are far away from the end of the business life cycle. Moreover, for that configuration of farmer-owners - older but owning 
Table 5 - Heckman two-step estimates of farming growth determinants based on growth rate in the period 2003-2007.

\begin{tabular}{|c|c|c|c|c|c|}
\hline & & & Model & & \\
\hline & (1) & (2) & (3) & (4) & (5) \\
\hline $\operatorname{Size}_{t-1}\left(\eta_{1}-1\right)$ & $\begin{array}{c}-0.405^{* * *} \\
(0.030)\end{array}$ & $\begin{array}{c}-0.412 * * * \\
(0.030)\end{array}$ & $\begin{array}{c}-0.340 * * * \\
(0.042)\end{array}$ & $\begin{array}{c}-0.316^{* * *} \\
(0.032)\end{array}$ & $\begin{array}{c}-0.311 * * * \\
(0.097)\end{array}$ \\
\hline $\operatorname{Size}_{t-2}\left(\eta_{2}\right)$ & $\begin{array}{c}0.209^{* * *} \\
(0.030)\end{array}$ & $\begin{array}{c}0.202^{* * *} \\
(0.031)\end{array}$ & $\begin{array}{c}0.238 * * * \\
(0.033)\end{array}$ & $\begin{array}{r}0.201 * * \\
(0.092)\end{array}$ & $\begin{array}{c}0.199 * * \\
(0.092)\end{array}$ \\
\hline $\begin{array}{l}\text { Legal business format } \\
\text { Limited liability company (LLC) }\end{array}$ & - & $\begin{array}{c}0.074 * * \\
(0.032)\end{array}$ & $\begin{array}{r}0.082 * * \\
(0.034)\end{array}$ & $\begin{array}{l}-0.084 \\
(0.085)\end{array}$ & - \\
\hline $\begin{array}{l}\text { Employees-specific characteristics } \\
\mathrm{Age}_{\mathrm{t}-1}\end{array}$ & - & - & $\begin{array}{c}-0.143 * * * \\
(0.044)\end{array}$ & $\begin{array}{c}-0.246 * * \\
(0.124)\end{array}$ & $\begin{array}{c}-0.259 * * \\
(0.124)\end{array}$ \\
\hline Experience $_{t-1}$ & - & - & $\begin{array}{l}-0.010 \\
(0.017)\end{array}$ & $\begin{array}{c}0.045 \\
(0.049)\end{array}$ & $\begin{array}{c}0.042 \\
(0.049)\end{array}$ \\
\hline Top-education $_{t-1}$ & - & - & $\begin{array}{c}0.572 * * * \\
(0.220)\end{array}$ & $\begin{array}{l}-0.165 \\
(0.660)\end{array}$ & $\begin{array}{l}-0.192 \\
(0.660)\end{array}$ \\
\hline Owner-specific characteristics & & - & - & & \\
\hline Age $_{t-1}$ & - & - & - & $\begin{array}{c}0.246^{* *} \\
(0.122)\end{array}$ & $\begin{array}{l}0.225^{*} \\
(0.120)\end{array}$ \\
\hline Top-educated owner $r_{t-1}$ & - & - & - & $\begin{array}{c}0.097 \\
(0.104)\end{array}$ & $\begin{array}{c}0.094 \\
(0.104)\end{array}$ \\
\hline Experience $_{t-1}$ & - & - & - & $\begin{array}{c}-0.109 * * \\
(0.050)\end{array}$ & $\begin{array}{c}-0.096^{* *} \\
(0.049)\end{array}$ \\
\hline Lambda $(\lambda)$ & $\begin{array}{c}0.011 \\
(0.017)\end{array}$ & $\begin{array}{l}-0.011 \\
(0.019)\end{array}$ & $\begin{array}{c}0.511 * * * \\
(0.160)\end{array}$ & $\begin{array}{c}0.099 \\
(0.045)\end{array}$ & $\begin{array}{c}0.130 \\
(0.169)\end{array}$ \\
\hline $\begin{array}{l}\text { Wald } \chi^{2} \text { test }\left(\mathrm{H} 0: \eta_{1}=0 ; \eta_{2}=0\right) \\
{[p \text {-value] }}\end{array}$ & $\begin{array}{l}295.71 \\
{[0.000]}\end{array}$ & $\begin{array}{l}294.21 \\
{[0.000]}\end{array}$ & $\begin{array}{c}76.79 \\
{[0.000]}\end{array}$ & $\begin{array}{c}10.62 \\
{[0.000]}\end{array}$ & $\begin{array}{c}10.27 \\
{[0.000]}\end{array}$ \\
\hline Censored obs. & 2294 & 2294 & 2294 & 2294 & 2294 \\
\hline Uncensored obs. & 1632 & 1632 & 1533 & 305 & 305 \\
\hline
\end{tabular}

Legend: Figures in parentheses are robust standard errors (that is, standard errors corrected for heteroskedastic errors and lambda ( $\lambda$ ) estimated). *, **, and *** mean that coefficients are statistically significant at $10 \%$, $5 \%$, and $1 \%$ level. The probit estimation of selection equation is $\operatorname{Pr}\left(\psi_{i j(t)}=1\right)=\Phi\left(\alpha_{0}+\alpha_{1} s_{i j(t)}+\alpha_{2} s_{i j(t)}^{2}\right)+\xi_{i j(t)}$, where the covariates are firm size, augmented by its squared terms.

firms far away from the end of the business life cycle - there might be worse earning opportunities off-farming, suggesting that they may be more focused on attain higher profits to expand the farming firm operation. Nonetheless, these effects seem to vanish when we look at surviving farming firms in the most recent 3-year period, suggesting that there may be relevant changes on the driving factors of farming firms' growth.
On the human capital side, the farming firms' growth on the most recent 3-year period seems to be mainly nurtured by employees' skills and knowledge derived from higher education, regardless of the type of farming firm (with or without separation between ownership and management). Over the entire sampled period, this finding holds only for firms with separation between ownership and management. It suggests that the economic 
Table 6 - Heckman two-step estimates of farming growth determinants based on growth rate for the last 3-years period: 2005-2007.

\begin{tabular}{|c|c|c|c|c|c|}
\hline & & & Model & & \\
\hline & (1) & (2) & (3) & (4) & (5) \\
\hline $\operatorname{Size}_{t-1}\left(\eta_{1}-1\right)$ & $\begin{array}{c}-0.340 * * * \\
(0.032)\end{array}$ & $\begin{array}{c}-0.348 * * * \\
(0.032)\end{array}$ & $\begin{array}{c}-0.310^{* * *} \\
(0.043)\end{array}$ & $\begin{array}{c}-0.204 * * \\
(0.093)\end{array}$ & $\begin{array}{c}-0.201 * * \\
(0.093)\end{array}$ \\
\hline $\operatorname{Size}_{\mathrm{t}-2}\left(\eta_{2}\right)$ & $\begin{array}{c}0.220 * * * \\
(0.031)\end{array}$ & $\begin{array}{l}0.215^{* * *} \\
(0.011)\end{array}$ & $\begin{array}{c}0.213 * * * \\
(0.033)\end{array}$ & $\begin{array}{l}0.134^{*} \\
(0.079)\end{array}$ & $\begin{array}{l}0.134^{*} \\
(0.079)\end{array}$ \\
\hline $\begin{array}{l}\text { Legal business format } \\
\text { Limited liability company (LLC) }\end{array}$ & - & $\begin{array}{c}0.069 * * * \\
(0.026)\end{array}$ & $\begin{array}{c}0.080 * * * \\
(0.027)\end{array}$ & $\begin{array}{c}0.086 \\
(0.097)\end{array}$ & - \\
\hline Employees-specific characteristics & & & & & \\
\hline Age $_{t-1}$ & - & - & $\begin{array}{r}-0.050^{*} \\
(0.027)\end{array}$ & $\begin{array}{l}-0.089 \\
(0.097)\end{array}$ & $\begin{array}{l}-0.080 \\
(0.097)\end{array}$ \\
\hline Experience $_{\mathrm{t}-1}$ & - & - & $\begin{array}{c}0.022 \\
(0.015)\end{array}$ & $\begin{array}{c}0.035 \\
(0.038)\end{array}$ & $\begin{array}{c}0.036 \\
(0.039)\end{array}$ \\
\hline Top-education $_{\mathrm{t}-1}$ & - & - & $\begin{array}{c}0.439 * * * \\
(0.148)\end{array}$ & $\begin{array}{c}0.753 * * * \\
(0.239)\end{array}$ & $\begin{array}{c}0.766^{* * *} \\
(0.240)\end{array}$ \\
\hline Owner-specific characteristics & & - & - & & \\
\hline $\operatorname{Age}_{t-1}$ & - & - & - & $\begin{array}{c}0.101 \\
(0.096)\end{array}$ & $\begin{array}{c}0.123 \\
(0.095)\end{array}$ \\
\hline Top-educated owner ${ }_{t-1}$ & - & - & - & $\begin{array}{c}0.070 \\
(0.073)\end{array}$ & $\begin{array}{c}0.075 \\
(0.073)\end{array}$ \\
\hline Experience $_{t-1}$ & - & - & - & $\begin{array}{l}-0.053 \\
(0.045)\end{array}$ & $\begin{array}{l}-0.072 * \\
(0.043)\end{array}$ \\
\hline Lambda $(\lambda)$ & $\begin{array}{c}0.006 \\
(0.009)\end{array}$ & $\begin{array}{c}-0.007 \\
(0.010)\end{array}$ & $\begin{array}{c}0.089 \\
(0.067)\end{array}$ & $\begin{array}{l}-0.056 \\
(0.113)\end{array}$ & $\begin{array}{c}-0.072 \\
(0.045)\end{array}$ \\
\hline $\begin{array}{l}\text { Wald } \chi^{2} \text { test }\left(\mathrm{H} 0: \eta_{1}=0 ; \eta_{2}=0\right) \\
{[p \text {-value] }}\end{array}$ & $\begin{array}{l}180.01 \\
{[0.000]}\end{array}$ & $\begin{array}{l}186.18 \\
{[0.000]}\end{array}$ & $\begin{array}{l}55.45 \\
{[0.000]}\end{array}$ & $\begin{array}{c}4.90 \\
{[0.086]}\end{array}$ & $\begin{array}{c}4.69 \\
{[0.096]}\end{array}$ \\
\hline Censored obs. & 8079 & 8079 & 8079 & 8079 & 8079 \\
\hline Uncensored obs. & 1632 & 1632 & 1546 & 266 & 266 \\
\hline
\end{tabular}

Legend: Figures in parentheses are robust standard errors (that is, standard errors corrected for heteroskedastic errors and lambda $(\lambda)$ estimated). $*, * *$, and $* * *$ mean that coefficients are statistically significant at $10 \%$, $5 \%$, and $1 \%$ level. The probit estimation of selection equation is $\operatorname{Pr}\left(\psi_{i j(t)}=1\right)=\Phi\left(\alpha_{0}+\alpha_{1} s_{i j(t)}+\alpha_{2} s_{i j(t)}^{2}\right)+\xi_{i j(t)}$, where the covariates are firm size, augmented by its squared terms.

payoff attained to employees' higher education has been enlarged and recognised by both types of farming firms. Conversely, the relevance to farming firm's growth of employees' age, as an indicator of ability to cope with increasing technological and market complexities of farming, seems to be undermined when we look at growth from the most recent 3-year period. Jointly, those results appear to suggest that farming firms are trying to balance youth with an academically qualified workforce, with an increasing economic payoff for the latter in the last 3 -years period.

\section{Conclusion}

The increasing technological and market complexities of modern farming make firms adapt to these changes in order for them to remain 
profitable and grow. The emphasis on human capital and on managerial training and expertise have been amplified as a way to cope with a more market-orientated sector characterised by technological innovation, increased competition worldwide, and reduced statutory subsidies and intervention measures. This paper attempts to empirically assess observable factors, in particular, investments in human capital and managerial capabilities, which may have power to shape farming firm's growth.

Overall, the results suggest that Portuguese farming firms' growth depends on firm's size. More interestingly, the steadiness of the farming firms' size-growth equilibrium could be attained in the long run, as small firms seem to grow faster than large ones, possibly as a mechanism for exploiting economies of scale. That farm sizegrowth convergence calls for policies supporting small firms in order to assist survival and growth. In particular, public policies based on public financial support programs targeting small-scale farming firms and the development of support services for those farming firms could endorse firm's growth and economic development of the Portuguese farming system.

Regarding the organizational structure of farming firms, inferred by the legal business format, there is robust evidence supporting the proposition that farming firms with ownership disentangled from management grow faster than other types of firms. This suggests that differences in the management input are relevant. Farming firms with good managerial capabilities could yield profits to financing growth. More importantly, those capabilities appear to be more easily developed in a context of separation of management from ownership than in farming firms where the farmer-owners accumulated management liabilities. In the latter, the farmer-owner's demographic characteristics seem to be a weak predictor of firm's growth, suggesting that this type of firms could lack important managerial capabilities.

Conversely, the effect of demographic characteristics of employees, as an indicator of investments in human capital, on farming firm's growth suggests that hiring young and academically qualified employees could yield a higher economic payoff, measured by firm's growth. This finding shows, nonetheless, some instability over the alternative time span used to compute growth, suggesting that investments in human capital have been adapted to the new context of Portuguese agricultural sector.

The empirical findings are relevant for agricultural policies and have implications upon farming sector restructuring and economic development in the Portuguese farming system. An important policy issue is how to improve human capital in agricultural areas and which policies would favour the selection and retention of young and academically qualified employees in order to improve farming efficiency and to stimulate the creation of services start-ups applied to the agricultural sector. Complementarily, farming firm's human resource management should be able to valuate those employees and to mitigate the labour- competitive advantage of offfarming activities. On the other hand, farming firm's organizational structure has to be outlined in such way that promotes and attracts managerial capabilities, regardless of ownership structure. In this sense, agricultural policies should promote the deployment of critical resources - such as qualified employees and managerial skills - in order to nurture more efficient production models and, hence, to yield competitive gains and economic development.

\section{Acknowledgements}

This work was carried out within the funding financed by National Funds of the FCT - Portuguese Foundation for Science and Technology within the project "UID/ECO/03182/2019".

\section{References}

Adamopoulos T., Restucia D., 2014. The size distribution of farms and international productivity differences. American Economic Review, 104(6): 1667-1697.

Ahearn M., Yee J., Korb P., 2005. Effects of differing farm policies on farm structures and dynamics. American Journal of Agricultural Economics, 87(5), 1182-1189.

Akimowicz M., Magrini M.-B., Ridier A., Bergez J.E., Requier-Desjardins D., 2013. What influences 
farm size growth? An illustration in Southwestern France. Applied Economic Perpesctives and Policy, 35(2): 242-269.

Atterton J., Ward N., 2007. Diversification and Innovation in Traditional Land-based Industries (Chapter 2). In: Mahroum S., Atterton J., Ward N., Willians A., Naylor R., Hindle R., Rowe F., Rural Innovation. London: NESTA, pp. 12-23.

Bakucs Z., Bojnec S., Ferto I., Latruffe L., 2013. Farm size and growth in field crop and dairy farms in France, Hungary and Slovenia. Spanish Journal of Agricultural Research, 11(4): 869-881.

Bartolini F., Viaggi D., 2013. The Common Agricultural Policy and the determinants of Changes in EU farm size. Land USE Policy, 31: 126-135.

Bremmer J., Oude Lansink A., Olson K., Baltussen W., Huirne R., 2002. Analysis of farm development in Dutch agriculture and horticulture. Presented at the 13th International Management Congress, Wageningen, The Netherlands, 7-12 July.

Chesher A., 1979. Testing the Law of Proportionate Effect. Journal of Industrial Economics, 27: 403-411.

D’Amico M., Coppola A., Chinnici G., Di Vita G., Pappalardo G., 2013. Agricultural systems in the European Union: An analysis of regional differences. New Medit, 12 (4): 28-34.

Eastwood R., Lipton M., Newell A., 2010. Farm Size. In: Pingali P.L., Evenson R.E. (eds.), Handbook of Agricultural Economics. Burlington: Academic Press, vol. 4, pp. 3323-3397.

Ford S.A., Shonkwiler J.S., 1994. The effect of managerial ability on farm financial success. Agricultural and Resource Economics Review, 23: 150-157.

Gardebroek C., Turi K.N., Wijnands J.H.M., 2010. Growth dynamics of dairy processing firms in the European Union. Agricultural Economics, 41(3-4): 285-291.

Gollin D., Lagakos D., Waugh M.E., 2014a. The agricultural productivity gap. Quarterly Journal of Economics, 129(2): 939-993.

Gollin D., Lagakos D., Waugh M.E., 2014b. Agricultural productivity differences across countries. American Economic Review, 104(5): 165-170.

Hadrich J., 2011. Human capital and its effect on the farm business life cycle. Presented at Agricultural \& Applied Economics Association 2011 Annual Meeting, Pittsburgh, Pennsylvania, 24-26 July.

Key N., Roberts M., 2007. Do government payments influence farm size and survival?. Journal of Agricultural and Resource Economics, 32(2): 330-349.

Kimhi A., Bollman R., 1999. Family Farm Dynamics in Canada and Israel: The Case of Farm Exits. $A g$ ricultural Economics, 21: 69-79.
Lotti F., Santarelli E., Vivarelli M., 2009. Defending Gibrat's Law as a Long-Run Regularity. Small Business Economics, 32: 31-44.

Marris R. 1963. A Model of the 'Managerial' enterprise. Quarterly Journal of Economics, 77(2): 185209.

Marris R., 1964. The Economic Theory of Managerial Capitalism. London: Macmillan.

Marsden T., Smith E., 2005. Ecological entrepreneurship: sustainable development in local communities through quality food production and local branding. Geoforum, 36(4): 440-451.

McElwee G., 2006. Farmer's as entrepreneurs: developing competitive skills. Journal of Developmental Entrepreneurship, 11(3): 187-206.

McElwee G., Robson A., 2005. Diversifying the farm: opportunities and barriers. Finnish Journal of Rural Research and Policy, 4(1): 84-96.

Melhim A., O’Donoghue E., Shumway C., 2009. What Does Initial Farm Size Imply About Growth and Diversification?. Journal of Agricultural and Applied Economics, 41(1): 193-206.

Mueller D.C., 1969. A Theory of Conglomerate Mergers. Quarterly Journal of Economics, 83(4), 643-659.

Penrose E., 1959. The Theory of the Growth of the Firm. New York, NY: John Wiley \& Sons.

Piet L., Latruffe L., Le Mouel C., Desjeux Y., 2012. How do agricultural policies influence farm size inequality? The example of France. European Review of Agricultural Economics, 39(1): 5-28.

Pyysiäinen J., McElwee G., Anderson A., Vesala K., 2006. Developing the entrepreneurial skills of farmers; some myths explored. International Journal of Entrepreneurial Behaviour and Research, 12(1): 21-39

Rizov M., Mathijs E., 2003. Farm Survival and Growth in Transition Economies: Theory and Empirical Evidence from Hungary. Post-Communist Economies, 15(2): 227-242.

Shapiro D., Bollman R., Ehrensaft P., 1987. Farm size and growth in Canada. American Journal of Agricultural Economics, 69(2): 477-483.

Sumner D., 2014. American Farms Keep Growing: Size, Productivity, and Policy. Journal of Economic Perspectives, 28(1): 147-166.

Sumner D., Leiby J., 1987. An econometric analysis of the effects of human capital on size and growth among Dairy Farms. American Journal of Agricultural Economics, 69(2): 465-470.

Upton M., Haworth S., 1987. The Growth of farms. European Review of Agricultural Economics, 14(4): 351-356. 
Villatoro M., Langemeier M., 2006. Factors Impacting on Farm Growth. Journal of American Society of Farms Managers and Rural Appraisers, 69: 74-80.

Weiss C.R., 1999. Farm growth and survival: econometric evidence for individual farms in Upper Austria. American Journal of Agricultural Economics, 81(1): 103-116.
Wooldridge J.M., 2002. Econometric Analysis of Cross Section and Panel Data. The MIT Press.

Zepeda L., 1990. Adoption of capital versus management intensive technologies. Canadian Journal of Agricultural Economics, 38: 457-469.

Zimmermann A., Heckelei T., 2012. Structural change of European dairy farms - A cross-regional analysis. Journal of Agricultural Economics, 63(3): 576-603. 